KUTASI GÁBOR ${ }^{1}$

\title{
A KöZgAZDASÁGTAN VISZONYA
}

\section{A TERMÉSZETES VILÁGHOZ A XXI. SZÁZADBAN THE RELATION OF ECONOMICS TO THE NATURE IN THE $21 S T$ CENTURY}

A klímaváltozás problémájának globális felismerését az 1987-es Brundtland-jelentéstől szokás datálni. Azóta eltelt három évtized, de a közgazdaságtanban mintha még mindig egy elkülönült szegmens lenne azon tanulmányok köre, amely a globális felmelegedés hosszú távú kihívásaival és hatásaival foglalkozik, miközben mintha a növekedési modellek nem igazán integrálták volna azt a korlátot az újkeynesi modellekbe, hogy az eröforrások végesek. Söt, még távolabb áll a fösodor attól, hogy a modellek tudomást vegyenek arról, hogy maga a természeti környezet és az éghajlat terhelhetösége véges, és rongálódása visszafordíthatatlan folyamatokhoz vezethet emberi léptékben mért idötávlatokban. A következö cikk arra vállalkozik, hogy a klímaváltozás példáján keresztül megvizsgálja, meddig jutott az uralkodó közgazdaságtan a természeti környezet korlátosságának figyelembevételében, és milyen irányok nyíltak meg arra, hogy még hatékonyabban integrálja az éghajlati problémát a modellekbe.

The global recognition of climate change problem is commonly attributed to the Brundtland report in 1987. Since then, three decades have passed, but in economics, it is still a separate segment of studies focusing on the long-term challenges and impacts of global warming, while it seems that short and medium-term growth models did not really integrate the constraint into the New Keynesian models that the resources are finite. Indeed, it is even farther from the mainstream models to reckon with the finite load capacity of the climate and to recognize that the climate damages can lead to irreversible processes at human time-scale. The following article aims to explore, through an example of climate change, how far the mainstream economics has got in taking the limits of the natural environment into account, and what kind of ways have become open to integrate the climate problems into the models more effectively.

„Mikor kell kitermelni az erdöt [...]? [A]mikor az erdö növekedési üteme egyenlö a kamatlábbal." H. L. Varian „Mikroökonómia középfokon”

\section{A KözgazdaságTAN VISZONYA A TERMÉSZETES VILÁGHOZ}

A világgazdaság és a makroökonómia viszonyát alaposan megrengette a 2009-es globális pénzügyi és gazdasági válság. A tíz évvel ezelőtti váratlan világválság egyben a közgazdaságtani elmé-

\footnotetext{
${ }^{1}$ egyetemi docens, MNB Tanszék, Budapesti Corvinus Egyetem
} 
let válságát is elhozta, megújult hévvel lehetett kritizálni a DSGE modellt, a válságkezelésre alkalmatlannak tartott neoliberális elméletet és gazdaságpolitikát. Tíz év telt el a gazdasági és elméleti válság óta, de nyoma sincs sem új modellnek, sem új paradigmának. Ez ösztönözte a Rethinking Economics csoportot arra, hogy közzé tegyék 33 pontjukat a közgazdaságtan megreformálásával kapcsolatban [Rethinking Economics, 2017]. Céljuk a pluralizmus elérése, azaz, hogy a különböző elméletek, modellek és iskolák megjelenhessenek az oktatásban és a publikációs felületeken.

A közgazdaságtan tartalmi kihívásaival kapcsolatban számos tanulmány született. Többek között Ábel és szerzőtársai [2016] alapvető közgazdasági ellentmondásokra mutattak rá. Csaba [2018] az intézményi közgazdaságtan és a fösodor viszonyát vizsgálva azt állítja, hogy az uralkodó közgazdaságtan és az intézményi irányzat „elvontsági szintje és tárgyalási módja tartósan és egyre erőteljesebben széttart egymástól," ami arra vezethető vissza, hogy a fősodor elsődlegesnek tartja a módszertant és csak másodlagosnak a tartalom társadalmi jelentőségét. Danišková és Fidrmuc [2012] az újkeynesi Phillips-görbén keresztül szemlélteti a modellek torzítását. Halmai [2015] vagy Benczes [2015] az európai növekedési modell müködőképességét vitatja. Sebestyén [2012] a gazdasági átmenet döntési modelljének tökéletlenségeire, míg Baranyai [2018] az egyenlőtlenedés modellezési problémájára mutat rá. Matolcsy és Palotai [2018], Vonnák [2017], Krekó és szerzőtársai [2012], illetve Baksay és Palotai [2017] elemzéseiből, valamint Lehmann [2018] interjújából megmutatkozik, hogy a gazdaságpolitika is megkezdte az új megközelítések keresését. Banai és Kolozsi [2017] ágazati szinten keresi a fenntartható növekedés lehetöségeit.

Kérdés, hogy a pluralizmus módszertani vagy tartalmi értelemben értendő-e. A módszertani pluralizmus azt jelentené, hogy a ma uralkodó újkeynesi modell (amit új monetarista szintézisnek is neveznek) matematizált módszertana kiegészülne - elsősorban - a viselkedés-gazdaságtani módszerekkel. Ez esetben a közgazdaságtani elmélet evolúciója a neoklasszikus alapokon nyugvó modell továbbfejlesztése lesz. (A Thomas Kuhn-féle tudományfilozófia alapján, amíg nem jön egy alapvetően új paradigma, addig a meglévőn építkezik tovább a tudomány [Kuhn, 1962].)

A közgazdaságtan általános tartalmi és módszertani egyenetlenségei a fösodor természethez való hozzáállásában is megmutatkozik. A civilizáció mai fokán az ember annyira függetlennek gondolja magát a természeti környezettől, hogy nem csoda, ha a gondolkodásmódját tükröző modellek is képtelenek a gazdaságot a természetes élővilág részeként kezelni. Pont fordítva, úgy tekintik, hogy a természetet igába vonta a civilizált gazdaság. A közgazdaságtan társadalomtudományként definiálta magát, így megfeledkezett mindenröl, ami a társadalmon kívül van, azaz a természetről, mint az embertől függetlenül is létező entitásról. Bár foglalkozunk a gazdasági tevékenység káros hatásaival (negatív externáliák), de azt kizárólag a társadalom többi tagjára nézve vizsgáljuk - még a környezeti károk esetében is.

A fentieken túl akár odáig is elmehet a közgazdaságtan - ha a társadalmi viselkedés is ebbe az irányba mozdulna -, hogy a természetes élővilágot kiemeli az alárendelt termelési tényezők közül. A közgazdasági modellek nem tükröznek semmilyen felelősséget a természetért mint önálló entitásért mindaddig, amíg csupán eszközként és erőforrásként kezelik. A mai modellekben a természetes élővilág csupán egy az elfogyasztható javak és erőforrások közül. Ebben a szemléletben vergődik a globális felmelegedés, azaz a klímaváltozás közgazdasági elemzése is. Alapvetően az egyének és társadalmak költségei és hasznai vizsgálati keretében gondolkodik a társadalomtudomány. Elekes és Halmai [2015] a klímaváltozás és a gazdasági növekedés összefüggésében elsősorban még csak arra keresi a választ, hogy a meglévő növekedési modellben hogyan lehetne 
javítani a hatékonyságot az innováción, a földhasználaton, az energiaszektoron, a településszerkezet infrastrukturális kapcsolódásain keresztül. De vajon túlléphet-e egy társadalomtudományi terület azon, hogy a társadalom eszközként tekint a természeti környezetre, amelynek csupán a megújulását, fenntarthatóságát kell biztosítani, megfelelően becsatornázva a termelésbe?

Milyen kérdésekre kellene választ adnia egy korszerủ makrogazdasági modellnek? A Solowmodellen alapuló és széles körben elterjedt Cobb-Douglas termelési függvényből kiindulva a növekedési modellek alapállítása, hogy a gazdaságban hosszú távon beáll az állandósult növekedési szint. Vajon hogyan viszonyul ehhez az egyre bővülő globális energiaigény? Annak van-e állandósult szintje a valóságban és mi történik, ha ehhez nem elég az energiaforrás?

És, hogy a jövőbe tekintő tudományágak impulzusaival is foglalkozzunk: az ürkutatás ma azt vizsgálja tervezési fázisban, hogyan lehet az embert tömegesen más égitestekre (Hold, Mars) áttelepíteni, ott működő civil gazdasági tevékenységet, városokat létrehozni. Vajon a természettől elvonatkoztatott társadalmi és gazdasági modell más természeti és fizikai körülmények között is örökérvényűnek fog tünni? Vagy már a Földön sem ez a jó megoldás?

Nyilvánvaló, hogy miközben a közgazdaságtan a jólétet nevezi meg végső céljának, addig a gazdaságpolitika ezzel szemben a nemzetek és nemzetgazdaságok fennmaradásért való versengését (rat race) valósítja meg egymást növekedésbe, teljesítménybe való hajszolásával. Hogyan dőlt el a hidegháború? A Szovjetunió nem bírta finanszírozni a fegyverkezési és fogyasztási versenyt. Mi Kína célja ma? Legyőzni az USA-t gazdasági erőben, amire felépítheti világhatalmi elsőségét. Sorolhatnánk tovább a példákat arra, hogy minden kritika ellenére, továbbra is a GDP növekedése a legfontosabb gazdaságpolitikai indikátor. Nyilvánvalóan a degrowth iskola [Georgescu-Roegen, 1986] növekedést elvető megközelítése nem lesz soha egy, a maihoz hasonló világrendben uralkodó szemlélet. De vajon lehetséges-e az újkeynesi modellben gondolkodva, hogy a mai vagy akár csökkentett tőkeállomány mellett, csak a technológia fejlödésével, azaz a termelékenység javulásával növekedjenek a gazdaságok, mindenféle természeti erőforrásigény bővítése nélkül, ha a termelési függvényben a növekedés lehetséges forrásai között a tőkeállományt, a munkaerö-állományt és annak hatékonyságát, továbbá a technológiai fejlődést nevezzük meg? Mindezt azért, hogy a természet eltartóképességét ne feszítsék túl. A föld, mint tőkeeszköz kevésbé extenzív használata hozzájárulhatna a sivatagosodás és az esőerdőírtás lassításához, a nem megújuló energiaforrások iránti igény csökkentése az üvegházhatást mérsékelhetné, míg a nyersanyagokból készülő mennyiségi gépkapacitás helyett a termelékenység javulását szolgáló minőségi innováción alapuló termelésbővülés az életminőség javulását eredményezné. Érdemes olyan modellváltozatokon gondolkozni, amelyekben elkülöníthetö a fizikai és a pénzbeli tőke, hogy tesztelhető legyen a fizikai tőke növelése nélküli vagy akár csökkentésével járó, azaz a természettel és erőforrásaival takarékosan bánó gazdasági növekedés. Lényegében a Kiotói és a Párizsi Egyezmény széndioxidkvóta-plafonjai épp erre tettek javaslatot, amelynek nemzetközi elfogadottsága egyelöre elég vegyes.

\section{Hol TART MA A KLÍMAVÁLTOZÁS MODELLEZÉSE?}

Az az állítás egyáltalán nem állná meg a helyét, hogy az uralkodó irányzat nem foglalkozik a természeti környezet roncsolódásával. A globális felmelegedés általános növekedési modellekbe és gazdasági részterületekre koncentráló elemzésekbe egyaránt beépült. A 2018-ban Nobel-díjjal kitüntetett Nordhaus [1991], illetve ennek módosított változata, Nordhaus és Yang [1996] DICE 
modellje képes a klímaváltozás forgatókönyv-elemzésére hosszú távon. Beépíti a szén-dioxidfogyasztás hosszú távú növekedési hatását, természetesen szigorúan költség-haszon elemzés szemléletben. Mindezidáig azonban élesen elkülönül a rövid távú előrejelző és a hosszú távú forgatókönyvelemző modell.

A kereskedelempolitikai döntések klímaváltozást érintő felmelegedéssel kapcsolatos hatására vonatkozóan is kialakult a modellezési gyakorlat a CGE (Computable General Equilibrium, számítható általános egyensúly) alapú modellre építve, ahogy azt Balisteri és Rutherford [2011] kiválóan példázza. A környezeti hatásokról és módszertani lehetőségekről bővebben Holzer és Cottier [2015], Ecorys [2014], House of Commons Environmental Audit Committee [2015], Frankel és Rose [2005], Holladay [2008], UNEP-IISD [2005] tanulmányaiból tájékozódhatunk. ${ }^{1}$

A költségvetési politikába integrálja a klímaváltozás problematikáját Heller [2003], aki tanulmányában különböző hosszú távú államháztartási kihívásokkal szembesíti a fiskális politikát. Jones és Keen [2009] már a legutóbbi világgazdasági válság elején úgynevezett zöld növekedési pályában gondolkodott (green recovery), amely ötlet már megjelent Bossier és Bréchet [1995] tanulmányában is arra vonatkozóan, hogy hogyan lehetne az európai foglalkoztatási válságot úgy enyhíteni, hogy a béradók csökkentését a zöldadók emelésével helyettesítik, olcsóbbá téve a munkaerőt. Barker [1998] elő is állt az E3ME modellel (energy-environment-economy model of EU), amely kifejezetten a zöldadók energiahatékonyságra, foglalkoztatásra és versenyképességre gyakorolt együttes hatását modellezi ökonometriai eszközökkel.

Adózási kérdésekben - kiindulva a Pigou-adóból - számos modell született meg az adóhatás és a klímaváltozás összefüggésének vizsgálatára: Kim és szerzőtársai [2011], Cooper [1998], Pizer [1997], Nordhaus [2007]. Buchanan [1969] és Nye [2008] az üzemanyag-piaci adóhatást elemzi, Edlin és Karaca-Mandic [2006] a heterogén piacokra igazítja mindezt. Sinn [2008] felvázolja a zöld paradoxont, amely alapján a hatékony zöldadó felszámolja a saját adóalapját, ami költségvetési szempontból kedvezőtlen. Edenhofer és Kalkuhl [2011] teszteli is ennek a paradoxonnak a megvalósulását. Bossier és Bréchet [1995] az adórendszer egészét figyelembe véve vizsgálja a zöldadók korlátos lehetőségeit.

A szennyezés beárazására optimalizációs modellek léteznek a mikroökonómiából levezetve, amelyek figyelembe veszik a jólét optimalizálását, az intertemporális erőforráselosztást, vagy a változó diszkontrátát. (Lásd Kuik és szerzőtársai [2008], Azar [1999].) Sőt, a korlátos természeti erőforrások problematikája már beépült munkaerőpiaci modellbe [Lintz, 1992] és a Porter-féle versenyképességi gyémánt módosított változatába is [Berg-Holtzbrügge, 1997].

A klímaváltozás kérdése beépült a monetáris és pénzügyi politika modelljeibe is. A Bank of England [2015] tanulmánya is arra a következtetésre jut, hogy a globális felmelegedés és az erre tett hibás gazdaságpolitikai lépések rontják a pénzügyi stabilitást. Közvetlenül az éghajlati károkat elszenvedett és így fizetésképtelenné váló cégek, továbbá a részvényáresést esetleg elszenvedő olajipari cégek lehetnek a növekvő instabilitás kiindulópontjai. Dafermos és szerzőtársai [2017] mủhelytanulmánya a zöld QE programnak nevezett jegybanki alkalmazkodást vizsgálja ökológiai alapú makromodell segítségével. Tanulmányuk fókuszában az áll, hogyan hat a klímaváltozás

\footnotetext{
${ }^{1}$ Fidrmuc [2004] a neoklasszikus kereskedelmi modell felülvizsgálatával alapot teremt arra, hogy a gravitációs modellel a tranzakciós költségek megjeleníthetök legyenek a kereskedelmi modellekben. Így az externáliák a társadalmi költségekbe is beépíthetők.
} 
a pénzügyi stabilitásra és az árstabilitásra, és hogyan kell ehhez alkalmazkodnia a jegybanknak. Kiindulópontjuk, hogy a globális felmelegedés hatására pusztul a cégek tőkeeszközállománya és így a jövedelmezőségük is, amin keresztül pedig a likviditásuk is. Ez megnövelheti a fizetésképtelenséget, amely végül a pénzügyi stabilitást és a bankszektort is rombolja. Ha ezt ki akarják védeni tőkepiaci szereplők, akkor átcsoportosítják a befektetési portfóliójukat az éghajlatváltozás hatására (sic!), ami következtében a vállalati kötvények és részvények értéke csökkenni kezd. Emellett a növekvő pénzügyi instabilitás visszafogja a hitelek bővülését, ami kedvezőtlenül hat a zöld beruházások alakulására is. Így pedig éppen a klímaváltozás csillapítására tett erőfeszítések gyengülnek. Éppen ezért az ún. zöld szemléletü QE (jegybanki lazítás) mérsékelheti a felmelegedés okozta pénzügyi instabilitást és támogatja az éghajlatváltozás csillapítását. Eredményeik alapján alapvetően meghatározza a zöld monetáris program hatékonyságát az, hogy hogyan reagálnak a zöld beruházások az őket finanszírozó kötvények hozamának változására. Murphy és Hines [2010] valamint Campiglio [2016] is foglalkozott a zöld QE-vel, arra a következtetésre jutva, hogy a monetáris és pénzügyi politikának az alacsony szén-dioxid-kibocsátású gazdasági tevékenységek felé érdemes terelnie a finanszírozási forrásokat.

A monetáris célokkal hozza összefüggésbe a klímaváltozás hatását McKibbin és szerzötársai [2017] tanulmánya is, amely a zöldadók és a kvótaár inflációs célkitűzésre gyakorolt hatását méri fel. Megállapításuk szerint, habár az adóemelés önmagában egyszeri inflációs hatással jár, a zöldadók folyamatos emelésével számolnak, így valójában hosszabb periódusban is számolni kell vele az infláció célzásakor. A szén-dioxid kvóták ára pedig bizonytalanul változik és hat ki a termelés költségeire, így kockázatot jelent az árstabilitásra nézve.

\section{A KöRNYEZETTUdATOSSÁg A VISELKEDÉSI ÉS JÁTÉKELMÉLETI MODELLEKBEN}

Mindezen modellek azonban továbbra is a racionális döntéshozó és az önérdek követő (önző) egyén költség-haszon elemző keretin belül gondolkodnak. Igaz ugyan, hogy az egyéni önzésböl is levezethető az, hogy az egyének érdeke a természet megőrzése akár a saját életkörnyezetük megóvása, akár a leszármazottaik érdekében. A normaváltozás megfigyelhető a társadalomban. Kérdéses azonban a fenntarthatóság garanciája. A legmerészebben a viselkedéstudományi megközelítés hajlandó elmenni, mint azt Gowdy [2007] tanulmánya példázza, amely az idegtudományok (neuroscience) alapjain építi fel az egyént, akit nemcsak az értelem (racionalitás), hanem az érzelem is vezérel, és aki nem egyéni, hanem társadalmi döntésekben vesz részt adott intézményi és kulturális környezetben, és nem csak a saját szempontjait tartja szem elött. A Güth és szerzőtársai által [1982] kidolgozott, ultimatum game-nek nevezett döntéselméleti (és játékelméleti) modell azt állítja, hogy a homo oeconomicus megközelítést meghaladó motivációkban kell keresni az emberi viselkedés magyarázatát. Ez alapján ki kell mondani, hogy a pénzügyi ösztönzők hatása korlátos a környezeti és társadalmi problémák megoldásában. Valószínűleg az embernek nem is a materialista, fogyasztói társdalom a természetes viselkedési módja, ha a 20. század előtti kultúrákat vizsgáljuk. Gowdy [2017] megállapítja, hogy bizonyos problémák esetén - ilyen a klímaváltozás is - szükséges egy társadalmilag minimális létszám (threshold effect), akik hajlandók együttmüködni, hogy egyáltalán beinduljon bármiféle cselekvés a probléma kezelésére. Az együttmüködésre viszont csak akkor hajlandók a tömegek, ha a nem kooperáló szabályszegőket (free-rider) egyértelmüen meg lehet büntetni. Továbbá nagyon 
fontos, hogy az ember elsősorban azokkal hajlandó együttműködni, akiket a saját csoportjához tartozónak érez. Ez pedig a globális felmelegedésben a viselkedési kihívás: a teljes emberi fajt kell csoporton belülinek éreznie mindenkinek ahhoz, hogy igazán erős és hatékony kooperáció induljon meg [Gowdy, 2017: 642].

A környezet hatásának viselkedési megközelítéséhez intenzív kutatások kapcsolódnak a fogyasztói magatartás modellezése és a marketingkutatás területén. Csutora és Zsóka [2016] arra keresi a választ, hogy a jó életminőség, a boldog és elégedett élet hogyan biztosítható a Földön, miközben növekvő népességgel, ökológiai korlátokkal és növekvő fogyasztói elvárásokkal szembesül a világ. Miként hat minderre a spiritualitás, hogyan befolyásolja a boldog élet fenntarthatóságát a vallásos és hogyan az ateista világnézet? Kutatásuk igazolja, hogy a spiritualitás hatással van a szubjektív jólétre és az ökológiai lábnyom méretére is.

Csutora [2014] azt elemzi elméleti és empirikus megközelítésben is, hogy miként alakulhat ki látványos szakadék az egyéni cselekvések iránya és azok együttes hatása között. Azaz miért következik be az, hogy a szándékok és tettek hatását felülírhatja a társadalmi gazdasági tényezőkből adódó tehetetlenség, vagyis a kritikus tömeg hiánya, szervezeti-infrastrukturális tényezők, kompenzációs hatások, egymás hatását kioltó cselekvések? Következtetése, hogy az önkéntességre alapozó megközelítés sokszor túlbecsüli a fogyasztó lehetőségeit és szuverenitását az ökológiai lábnyom és a környezettudatosság esetében.

Hofmeister-Tóth és szerzőtársai [2013] empirikus kutatása a környezettudatos fogyasztói preferenciákat, ezen belül a környezeti motiváció és a pszichográfiai tényezők fogyasztói magatartásra gyakorolt hatását elemzi. Ennek keretében vizsgálják a környezeti motívumokat és az általános környezetbarát viselkedést, valamint a személyes értékrend, a környezet iránti attitüd és az észlelt környezeti következmények szerepét.

A viselkedési megközelítés mellett a játékelméleti is kitermelte a maga modelljeit. A klímatárgyalásokra vonatkozóan egyrészt létrejött a Tóth-Ciscar-Courtois-Forgó sztochasztikus modell [Tóth et al., 2001], másrészt a Forgó-Fülöp-Prill modell [Forgó et al., 2003]. Mindezek tovább fejleszthetők a tárgyalásra vonatkozó játékelméletek olyan példáival, mint Dezső és szerzőtársai [2015], illetve Dezső és Neszveda [2012] tanulmányai.

\section{KöVETKEZTETÉSEK}

A globális felmelegedésről folyton beszélünk, de a hosszú távú következményeit még nem építettük be sem a hétköznapi gondolkodásunkba, sem az általánosan elterjedt növekedési modellekbe. A makrogazdasági modellek végtelen időhorizonttal számolnak és a tőketényezőket korlátokkal nem számoló változókkal modellezik, legalábbis, ami a termelési tényezőket illeti, miközben nagyon is végesek a valós erőforrások. A növekedési függvény három tényezője a technológia, a tőkeeszközök és a munkaerő. Érdemes lenne végiggondolni, hogy a mai, vagy akár csökkentett tőkeállomány mellett, csak a technológia fejlődésével, azaz a termelékenység javulásával, hogyan lehetne növekedni úgy, hogy a természet eltartóképességét nem feszítjük túl.

A természet nem a gazdaság eszköze és eröforrása, hanem a kontextusa és keretrendszere. Nem egyszerűen arról van szó, hogy kimerül egy nyersanyag és pótolni kell valami új megoldással, hanem arról, hogy belátható időn belül az emberi társadalom - amelyet a közgazdaságtan társadalomtudományként vizsgál - nem képes mással helyettesíteni a Földet. Ezért talán hibás megközelítés a természetes környezetet egyszerüen a termelési tényezők közé sorolni. A 
túlhasználat fogalmát ismeri a mikroökonómia-alapú környezet-gazdaságtan, az irreverzibilitás fogalmát használja a posztkeynesi fejlődés-gazdaságtan. A nemzetközi szervezetek és nemzeti kormányok által alkalmazott növekedési forgatókönyveket elemző, döntés-előkészítő modellek esetében nem árt, ha képesek az összeomlási pontokat is figyelembe venni. A visszafordíthatatlan károsodás, a túlhasználat következtében kimerülö bányák, elsivatagosodó területek, víz alá kerülő városok, eltűnő tengeri és szárazföldi állatvilág stb. figyelmen kívül hagyása aláássa a növekedést. Ha ezt a modell nem tudja kezelni, akkor a valóságtól elrugaszkodott növekedési pályát vetíthet elöre, ami hibás döntésekhez vezethet.

A környezet-gazdaságtan olyan terület, ahol az elmúlt évtizedek felismerései alapján valódi paradigmaváltást lehetne végrehajtani: a természet nem a gazdaság eszköze és erőforrása, hanem a kontextusa és keretrendszere. Ez a szemléletváltás azután megjeleníthető lenne a makrogazdasági, piaci és vállalati modellekben is.

\section{Felhasznált irodalom}

Ábel István, Lehmann Kristóf, Tapaszti Attila (2016): A pénz és a bankok ellentmondásos kezelése a makroökonómiában. Hitelintézeti Szemle, 15:(2) p. 33-58.

Azar C. (1999): Weight factors in cost-benefit analysis of climate change. Environmental and Resource Economics 13:() pp. 249-268.

Baksay Gergely, Palotai Dániel (2017): Válságkezelés és gazdasági reformok Magyarországon, 2010-2016. Közgazdasági Szemle, 64:(7-8) pp. 698-722.

Balistreri E. J., Rutherford T. F. (2011): Computing General Equilibrium Theories of Monopolistic Competition and Heterogeneous Firms. In: Dixon P.B., Jorgenson D.W. (szerk.) (2011): Handbook of Computable General Equilibrium Modeling. Elsevier, Amsterdam

Banai Ádám, Kolozsi Pál Péter (2018): Fenntartható hitelpiac, fenntartható fejlődés. Köz-gazdaság, 13:(2) pp. 135-143.

Bank of England (2015) The Impact of Climate Change on the UK Insurance Sector: a Climate Change adaptation report by the Prudential Regulation Authority. https://www.bankofengland.co.uk/prudential-regulation/publication/2015/the-impact-of-climate-changeon-the-uk-insurance-sector Letöltés: 2018. aug. 23.

Baranyai Eszter (2018) Egyenlőtlenség és gazdaság: hogyan hatnak egymásra? Köz-Gazdaság, kézirat

Barker T. (1998): The effects on competitiveness of coordinated versus unilateral fiscal policies reducing GHG emissions in the EU: an assessment of a 10\% reduction by 2010 using the E3ME model. Energy Policy, 26:(14) pp. 1083-1098.

Benczes István, Szent-Iványi Balázs (2015): The European economy in 2014: Fragile recovery and convergence. Journal of Common Market Studies 53:(s1) pp. 162-180.

Bossier F., Bréchet T. (1995): A fiscal reform for increasing employment and mitigating CO2 emissions in Europe. Energy Policy, 23:(9) pp. 789-798.

Buchanan J. (1969): External Diseconomies, Corrective Taxes, and Market Structure. American Economic Review, 59:(1) pp. 174-177

Campiglio E. (2016) Beyond Carbon pricing: the role of banking and the monetary policy in financing the transition to a low-carbon economy. Ecological Economics. 121:(C), pp. 220-230

Cooper R. (1998): Toward a real treaty on global warming. Foreign Affairs 77:(2) pp. 66-79. 
Csaba László (2018): Az intézményi gazdaságtan és a fóáram. Közgazdasági Szemle 65:(1) pp. 1-23. Csutora Mária (2014): Összegződnek-e az egyéni törekvések? A cselekvés és az eredmény közötti szakadék problémája. Közgazdasági Szemle, LXI:(5) pp. 609-625.

Csutora Mária, Zsóka Ágnes (2016): Az értékvezérelt élet szerepe az ökológiai lábnyom csökkentésében Köz-Gazdaság 11:(4) pp. 49-63.

Dafermos Y., Nikolaidi M., Galanis G. (2017): Climate change, financial stability and monetary policy. Post Keynesian Economics Study Group Working Paper, No. 1712

Danišková K., Fidrmuc J. (2012): Meta-Analysis of the New Keynesian Phillips Curve. Working Papers 314, Leibniz Institut für Ost- und Südosteuropaforschung (Institute for East and Southeast European Studies).

Dezső L., Loewenstein G, Steinhart J, Neszveda G, Szászi B (2015): The pernicious role of asymmetric history in negotiations. Journal of Economic Behavior and Organization, 116: pp. 430-438.

Dezső Linda, Neszveda Gábor (2012): A kvázi- és általánosított hiperbolikus diszkontálás hosszú távon. SZIGMA, 43:(3-4) pp. 163-177.

Edenhofer O., Kalkuhl M. (2011): When do increasing carbon taxes accelerate global warming? A note on the green paradox. Energy Policy, 39:(4) pp. 2208-2212

Edlin, A. - Karaca-Mandic, P. (2006): The Accident Externality from Driving, Journal of Political Economy, 114:(5) pp. 931-955

Elekes Andrea, Halmai Péter (2015): Éghajlatváltozás és gazdasági növekedés: Alacsony széndioxid-kibocsátású gazdaság vs. gazdasági növekedés - kibékíthetetlen ellentét? Magyar Tudomány 176:(5) pp. 522-531.

Fidrmuc J. (2004): The core and periphery of the world economy. The Journal of International Trade \& Economic Development, Taylor \& Francis Journals, 13:(1) pp 89-106.

Forgó F., Szép J., Szidarovszky F. (1999): Introduction to the Theory of Games. Kluwer Academic Publishers, Dordrecht.

Frankel J. A., Rose A.K. (2005): Is Trade Good or Bad for the Environment? Sorting Out the Causality, The Review of Economics and Statistics 87:(1) pp. 85-91.

Georgescu-Roegen N. (1986): The Entropy Law and the Economic Process. Eastern Economic Journal 12:(1) pp. 3-25

Gowdy J. M. (2017): Behavioral Economics and Climate Change Policy. Journal of Economic Behavior and Organization, vol. 68:(3-4) pp. 632-644

Güth W., Schmittberger R., Scwartz B. (1982): An experimental analysis of ultimatum game bargaining. Journal of Economic Behavior and Organization, 3:(4) pp. 367-388.

Halmai Péter (2015): Az európai növekedési potenciál eróziója és válsága Közgazdasági Szemle 62:(4) pp. 379-414.

Heller P. S. (2003): Who Will Pay? Coping with Aging Societies, Climate Change, and Other Long-Term Fiscal Challenges International Monetary Fund, Washington

Hofmeister-Tóth Ágnes, Kasza-Kelemen Kata, Piskóti Marianna (2013): A környezetbarát fogyasztói magatartás formái, motivációi és a hátterükben álló pszichográfiai tényezők vizsgálata Magyarországon. Marketing és Menedzsment 47:(3) pp. 34-42.

Holladay S. (2008): Pollution from Consumption and the Trade and Environment Debate. Discussion Papers in Economics No. 08-06, Center for Economic Analysis, University of Colorado at Boulder 
Holzer K., Cottier T. (2015): Addressing climate change under preferential trade agreements: Towards alignment of carbon standards under the Transatlantic Trade and Investment Partnership. Global Environmental Change 35:(1) pp. 514-522

House of Commons Environmental Audit Committee (2015): Environmental risks of the TransAtlantic Trade \& Investment Partnership. House of Commons Environmental Audit Committee, London

Jones B., Keen M. (2009): Climate Policy and the Recovery. IMF Staff Position Note December 4, $2009 \mathrm{SPN} / 09 / 28$

Kim Y-D., Han H-O., Moon Y-S. (2011): The empirical effects of a gasoline tax on CO2 emissions reductions from transportation sector in Korea Energy Policy 39:(2) pp. 981-989

Kuhn Thomas S. (1962): The Structure of Scientific Revolutions. University of Chicago Press, Chicago, (magyarul: A tudományos forradalmak szerkezete. Gondolat, Budapest, 1984 és Osiris, Budapest, 2000, 2002)

Krekó Judit, Balogh Csaba, Lehmann Kristóf, Mátrai Róbert, Pulai György, Vonnák Balázs (2012): Nemkonvencionális jegybanki eszközök alkalmazásának nemzetközi tapasztalatai és hazai lehetőségei. MNB-tanulmányok. No. 100.

Kuik O., Buchner B., Catenacci M., Gloria A., Karakaya E., Tol R. S. J. (2008): Methodological aspects of recent climate change damage cost studies, The Integrated Assessment Journal 8:(1) pp. 9-40.

Lehmann Kristóf (2018): A gazdaságpolitikusok azok, akik a mélyreható változtatásokat kezdeményezve új alternatívákat keresnek - interjú Antoine Godin-nal. Köz-gazdaság, 13:(2) pp. 81-86.

Matolcsy György, Palotai Dániel (2018): A magyar modell: A válságkezelés magyar receptje a mediterrán út tükrében. Hitelintézeti Szemle, 17:(2) pp. 5-42.

McKibbin W., Morris C. A., Panton A. J., Wilcoxen, J. P. (2017): Climate Change and Monetary Policy: Dealing with Disruption. SSRN Electronic Journal. 10.2139/ssrn.3084399.

Murphy R., Hines, C. (2010): Green quantitative easing: paying for the economy we need. Finance for the Future. www.financeforthefuture.com/GreenQuEasing.pdf

Nordhaus W. D. (1992): The "DICE" model: background and structure of a Dynamic Integrated Climate-Economy model of the economics of global warming. Cowles Foundation discussion paper no. 1009

Nordhaus W.D., Yang Z (1996): A Regional Dynamic General-Equilibrium Model of Alternative Climate-Change Strategies. American Economic Review, 86:(4) pp. 741-765

Nordhaus W.D., (2007): To tax or not to tax: alternative approaches to slowing global warming. Review of Environmental Economics and Policy 1:(1) pp. 26-44.

Nye J.V.C. (2008): The Pigou Problem. It is difficult to calculate the right tax in a world of imperfect Coasian bargains. Regulation Summer 2008, CATO Institute http://www.cato.org/ pubs/regulation/regv31n2/v31n2-5.pdf

Pizer W.A., (1997): Prices vs. quantities revisited: the case of climate change. Resource for the Future Discussion Paper, No. 98-02, Washington

Rethinking Economics (2017): 33 theses for an economics reeformation. http://www.rethinkeconomics.org/projects/reformation/

Sebestyén Géza (2012): Transition strategies and the crisis from a financial perspective International Journal of Business Insight and Transformation 5:(3) pp. 14-20. 
Sinn,H. (2008): Public policies against global warming: A supply side approach. International Tax and Public Finance 15:(4), pp. 360-394.

Toth F., Ciscar J.C., Courtois P., Forgo F., (2001): Strategic for integrated assessment of dynamic carbon emission reduction policies. EU SIADCERO Final Report ENG3-1999-00011, http://www.pik.de/ Letöltés: 2018. 08. 23.

UNEP-IISD (2005): Environment and Trade-A handbook, Second Edition, UNEP-IISD, http:// www.iisd.org/pdf/2005/envirotrade_handbook_2005.pdf Letöltés: 2018. 08. 23.

Vonnák Balázs (szerk.) (2017): Modern jegybanki gyakorlat. Magyar Nemzeti Bank, Budapest 